\title{
TICKS INFESTING AMPHIBIANS AND REPTILES IN PERNAMBUCO, NORTHEASTERN BRAZIL
}

\author{
FILIPE DANTAS-TORRES ${ }^{1}$; EDMILSON F. OLIVEIRA-FILHO²; FÁBIO ÂNGELO M. SOARES ${ }^{3}$; \\ BRUNO O.F. SOUZA²; RAUL BALTAZAR P. VALENÇA ${ }^{3}$; FABRÍCIO B. SÁ ${ }^{2}$
}

\begin{abstract}
DANTAS-TORRES, F.; OLIVEIRA-FILHO, E.F.; SOARES F.A.M.; SOUZA, B.O.F.; VALENÇA, R.B.P.; SÁ, F.B. Ticks infesting amphibians and reptiles in Pernambuco, Northeastern Brazil. [Carrapatos infestando anfíbios e répteis em Pernambuco, Nordeste do Brasil]. Revista Brasileira de Parasitologia Veterinária, v. 17, n. 4., p.218-221, 2008. Centro de Pesquisas Aggeu Magalhães-Fiocruz, Avenida Professor Moraes Rego s/n, Recife, PE 50670-420, Brasil. E-mail: fdt@cpqam.fiocruz.br

Ticks infesting amphibians and reptiles in the State of Pernambuco are reviewed, based on the current literature and new collections recently carried out by the authors. To date, three tick species have been found on amphibians and reptiles in Pernambuco. Amblyomma fuscum appears to be exclusively associated with Boa constrictor, its type host. Amblyomma rotundatum has a relatively low host-specificity, being found on toads, snakes, and iguana. Amblyomma dissimile has been found on a lizard and also small mammals (i.e., rodents and marsupials). New tickhost associations and locality records are given.
\end{abstract}

KEY WORDS: Amblyomma, cold-blooded animals, host-parasite associations.

\section{RESUMO}

Os carrapatos encontrados infestando anfíbios e répteis no Estado de Pernambuco são revisados com base na literatura atual e em novas coletas realizadas recentemente pelos autores. Até o momento, três espécies de carrapatos foram encontradas sobre anfíbios e répteis em Pernambuco. Amblyomma fuscum parece estar exclusivamente associado à Boa constrictor, seu hospedeiro-tipo. Amblyomma rotundatum tem uma especificidade parasitária relativamente baixa, sendo encontrado em sapos, serpentes e iguana. Amblyomma dissimile já foi encontrado sobre um lagarto e também sobre pequenos mamíferos (isto é, roedores e marsupiais). Novas associações carrapato-hospedeiro e novos registros de localidades são apresentados.

PALAVRAS-CHAVE: Amblyomma, animais de sangue frio, associações parasito-hospedeiro.

\section{INTRODUCTION}

Ticks (Acari: Ixodida) are ectoparasites of great medical and veterinary significance; that is, they can cause severe losses

\footnotetext{
${ }^{1}$ Centro de Pesquisas Aggeu Magalhães-Fiocruz, Avenida Professor Moraes Rego s/n, Recife, PE 50670-420, Brasil. Bolsista CAPES. E-mail: fdt@cpqam.fiocruz.br

${ }^{2}$ Universidade Federal Rural de Pernambuco, Rua Dom Manoel de Medeiros s/n, Recife, PE52171-900, Brasil.

${ }^{3}$ Faculdade Frassinetti do Recife, Av. Conde da Boa Vista 921, Boa Vista, Recife, PE 50060-002, Brasil.
}

to livestock industry and transmit many pathogens to both humans and domestic animals. Ticks are widely distributed in the world and parasitize an enormous variety of hosts, infesting all classes of vertebrates, from small amphibians and reptiles to large mammals (JONGEJAN; UILENBERG, 2004; ONOFRIO et al., 2006; DANTAS-TORRES; FIGUEREDO; 2006; NAVA et al., 2007).

The Brazilian tick fauna is currently known to consist of approximately 60 valid species. Most species are in the genus Amblyomma, to which all ticks associated with ectotherms ('coldblooded animals') belong to (ARAGÃO, 1936; ARAGÃO; FONSECA, 1961; EVANS et al., 2000; GUIMARÃES et al., 2001; TEIXEIRA et al., 2003; ONOFRIO et al., 2006).

A limited amount of information about the taxonomy and ecology of ticks infesting ectotherms in the Northeastern region of Brazil is currently available. In the present article, ticks parasitizing amphibians and reptiles in the state of Pernambuco are reviewed based on recent collections of ticks from different hosts and localities, as well as based on a comprehensive review of relevant literature.

\section{MATERIAL AND METHODS}

The present study is based on recent collections of ticks, from different hosts and localities (Igarassu, 07050'03" S, 345'ㄹ" W; Recife, 0803'14" S, 3452'52" W; São Lourenço da Mata, $08^{\circ} 00^{\prime} 08^{\prime \prime}$ S, 3501'06" W) in Pernambuco, 
and a thorough appraisal of relevant scientific literature. Part of the new material presented in this study has been deposited in the ixodid collection (accession number: IOC-IXO0697) of the Instituto Oswaldo Cruz, Rio de Janeiro, Brazil. The remnant specimens are currently in the collection of the first author of this paper (DANTAS-TORRES, F.).

From October 2005 to August 2007, ticks were casually collected by the authors during different field missions. As a rule, ticks were collected manually and preserved in alcohol $70 \%$. The identification at species level was carried out under stereomicroscope. Adult ticks were identified according to taxonomic keys provided by Aragão and Fonseca (1961) and Guimarães et al. (2001), whereas nymphs were identified based on the keys of Keirans and Durden (1998). Larvae were identified to genus level only.

Nomenclature of ticks is according to the most recent list of valid genus and species of ticks of the world (BARKER; MURRELL, 2004) and nomenclature of hosts is according to the lists of Brazilian amphibians and reptiles adopted by the Sociedade Brasileira de Herpetologia (2007a, 2007b).

For convenience, ticks are listed alphabetically. Whenever available, information regarding host, local, and date from new and previously reported material are provided. Whenever relevant, comments on either new or previously reported material are given.

\section{RESULTS}

Three species of ticks are known to infest amphibians and reptiles in Pernambuco. All of them belong to the genus Amblyomma.

Amblyomma dissimile Koch, 1844

New material: 3 nymphs from Tropidurus hispidus (Spix, 1825) (Squamata: Tropiduridae), São Lourenço da Mata, 12/ 05/2007. Previously reported material: from an unknown host in Tapéra (a locality of the municipality of Moreno) (ARAGÃO, 1936).

Comments: Aragão (1936) included Pernambuco in the geographical distribution of A. dissimile in Brazil, but without host data. Ticks of this species have also previously been found parasitizing wild rodents - .e., Thrichomys apereoides (Lund, 1839), Oryzomys subflavus (Wagner, 1842), and Cavia aperea Erxleben, 1777 - and marsupials - i.e., Monodelphis domestica (Wagner, 1842) and Didelphis albiventris (Lund, 1840) - in the municipalities of Inajá and Floresta, which are located in the semi-arid region of Pernambuco (BOTELHO et al., 2002).

\section{Amblyomma fuscum Neumann, 1907}

New material: 1 male from Boa constrictor Linnaeus, 1758 (Squamata: Boidae), Igarassú, 30/07/2007; 7 males and 1 female from B. constrictor, São Lourenço da Mata, 05/05/ 2007. Previously reported material: from $B$. constrictor in Recife (CUNHA et al., 1999).

Comments: In Pernambuco, A. fuscum appears to be exclusively associated with $B$. constrictor, its type host. Except for nine females recently collected on a lizard in the State of Rio Grande do Sul (MARTINS et al., 2007), females of $A$. fuscum are rarely observed in nature. Among nine specimens we examined in this study, there was only one female. The characteristics of this A. fuscum female include its large body size, presence of a strong, sclerotised tubercle situated anteriorly on coxa I, hypostomal dentition $4 / 4$, and scutum ornate with deep and sparse punctuations close to eyes and cervical grooves, extending to posterior and lateral margin (Figure 1).

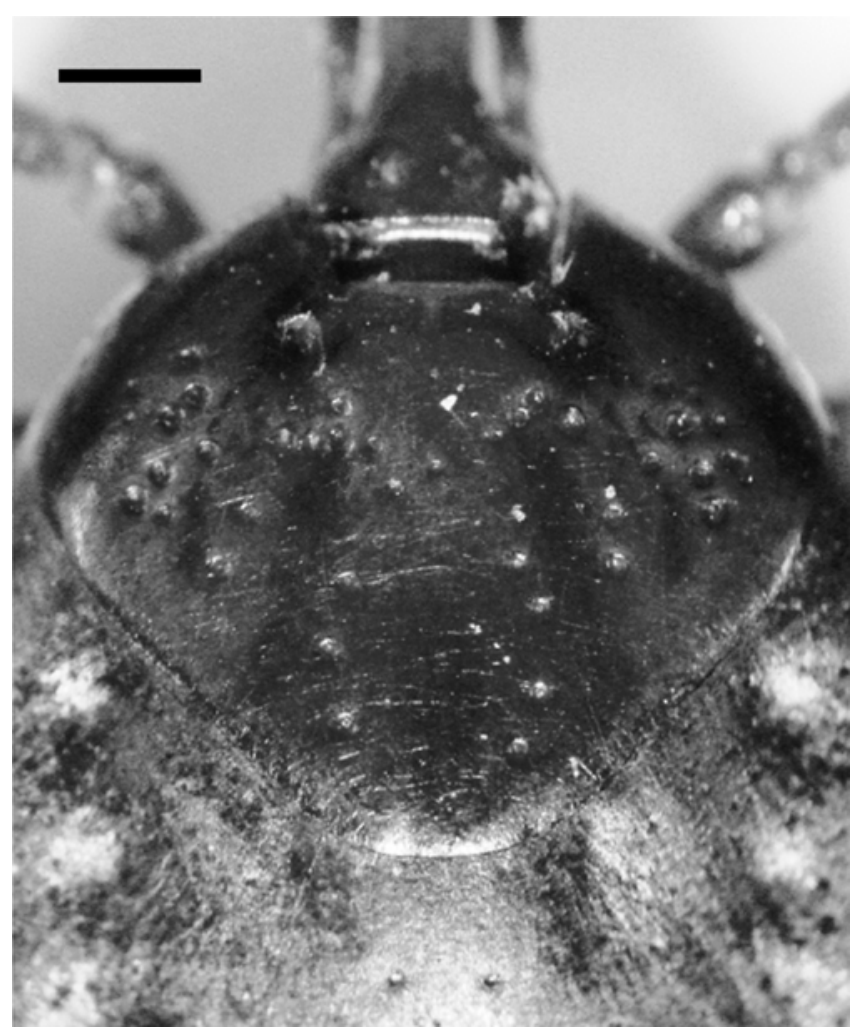

Figure 1. Amblyomma fuscum female, dorsal view. Scutum with deep and sparse punctuations close to eyes and cervical grooves, extending to posterior and lateral margin (scale bar=500 $\mu \mathrm{m}$ ).

Amblyomma rotundatum Koch, 1844

(=Amblyomma agamum Aragão, 1912)

New material: 2 females from Iguana iguana (Linnaeus, 1758) (Squamata: Iguanidae), Igarassú, 24/10/2005; 3 females from B. constrictor, São Lourenço da Mata, 05/05/2007; 1 female from B. constrictor, Recife, 01/08/2007. Previously reported material: from Bufo crucifer Wied-Neuwied, 1821, B. granulosus Spix, 1824, and B. paracnemis Lutz, 1925 in São Lourenço da Mata (SANTOS et al., 2002); from captive snakes [B. constrictor, Corallus hortulanus (Linnaeus, 1758), and Epicrates cenchria (Linnaeus, 1758)] in Recife (CUNHA et al., 2003); from Crotalus durissus cascavella (Wagler, 1842) in Igarassú (DANTAS-TORRES et al., 2005).

Comments: Amblyomma rotundatum appears to be the most common tick found on reptiles in Pernambuco. Aragão (1936) included Pernambuco in the distribution of $A$. rotundatum in Brazil, but without host or locality data for this 


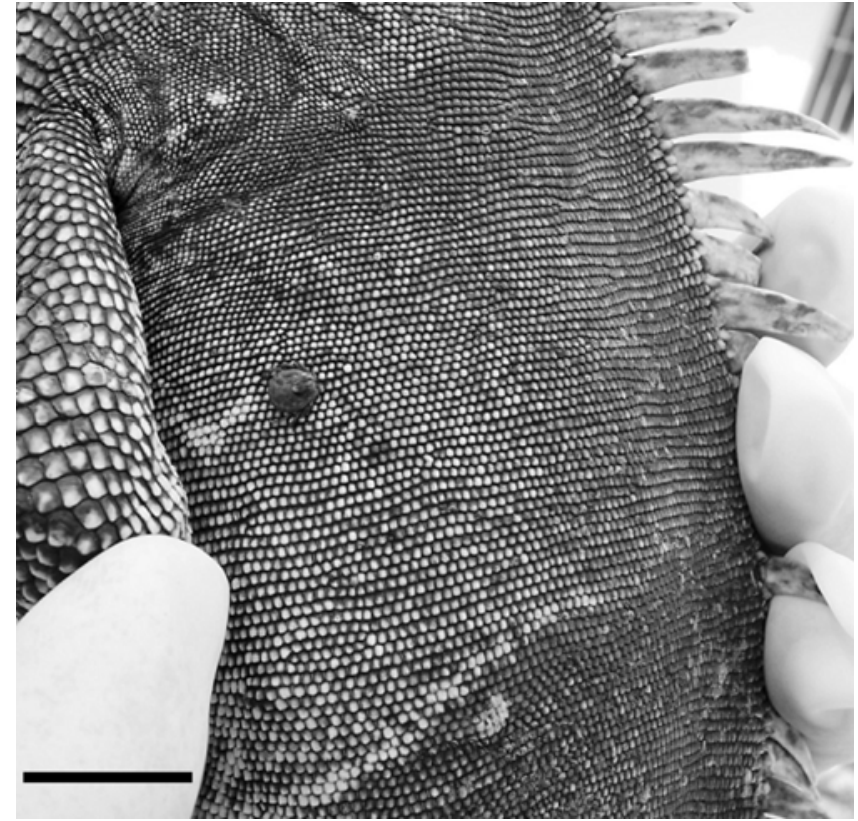

Figure 2. An adult female $A$. rotundatum well attached to the iguana's skin (scale bar $=15 \mu \mathrm{m})$.

state. This is the first record of A. rotundatum on I. iguana (Figure 2) in Pernambuco and possibly the first record of this tick-host association in Brazil to be formally published in the scientific literature.

Amblyomma sp.

New material: 7 larvae from T. hispidus, São Lourenço da Mata, 12/05/2007; 2 larvae from Tantilla melanocephala (Linnaeus, 1758), São Lourenço da Mata, 10/09/2007. Previously reported material: none. Comments: These larvae were collected on a lizard and on a snake from the municipality of São Lourenço da Mata, in the same locality where an exemplar of $T$. hispidus was found to be infested by three nymphs of $A$. dissimile. Further studies are greatly appreciated to provide further data on tick infesting lizards and snakes in São Lourenço da Mata. The finding of Amblyomma ticks on T. melanocephala represents a new host record.

\section{DISCUSSION}

Amblyomma fuscum is also found predominantly on amphibians and reptiles (ARAGÃO, 1936; ARAGÃO; FONSECA, 1961; CUNHA et al., 1999; ONOFRIO et al., 2006). Its distribution appears to be restricted to Brazil (BARROSBATTESTI et al., 2005; MARQUES et al., 2006; ONOFRIO et al., 2006; MARTINS et al., 2007). Insights derived from recent studies indicate that $A$. fuscum presents a relatively low host-specificity; it can be found on mammals (BRUM et al., 2003; BARROS-BATTESTI et al., 2005), including humans (MARQUES et al., 2006). The finding of A. fuscum ticks infesting two exemplars of $B$. constrictor from the Atlantic Rainforest region of Pernambuco is worthy of note. Firstly, it confirms a previous record (CUNHA et al., 1999) of the occurrence of this rare Neotropical tick species in Pernambuco. Moreover, it suggests that the distribution of $A$. fuscum, which was previously considered to be restricted to the South and Southeast Brazil (MARTINS et al., 2007), has been underestimated.

A malformed male A. fuscum was noticed among the specimens examined in the present study. This adult male had 10 instead of 11 festoons (Figure 3). Cases of malformations have sporadically been noticed in hard ticks (Labruna Et Al., 2000; Estrada-Peña, 2001; Labruna et al., 2002).

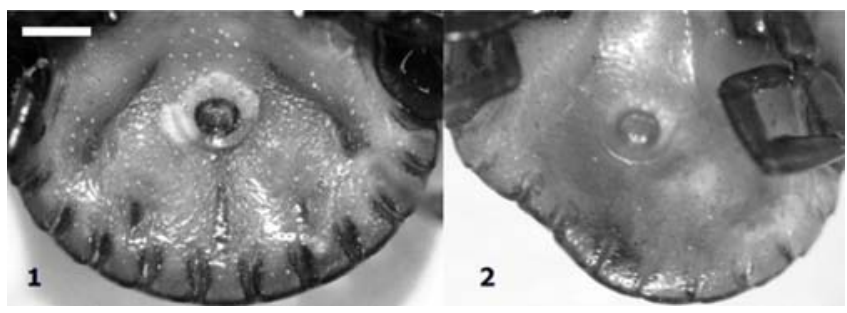

Figure 3. Amblyomma fuscum males, ventral view. 1. A normal male specimen with 11 festoons. 2. A male with 10 festoons (scale bar $=500 \mu \mathrm{m}$ )

We were able to promptly identify the three nymphs of $A$. dissimile collected from $T$. hispidus, using the keys provided by Keirans and Durden (1998). However, it is important to remember that these keys do not cover nymphs of all $\mathrm{Am}$ blyomma species found in Brazil. Whenever possible, it is recommended to rear wild-caught immature ticks in the laboratory until they mount into adults, allowing an easier and more precise identification.

Finally, as most information on ticks infesting amphibians and reptiles in Pernambuco comes from casual studies, which were carried out in a very limited geographical region of this state, further field missions aiming at improve our current understanding on taxonomy and biology of ticks parasitizing ectotherms in Pernambuco would be greatly desirable.

Acknowledgments:- Thanks to Marinete Amorim for confirming the tick species from the iguana, to Marcelo Bahia Labruna for his useful comments, and to Alessandra R. de Albuquerque for English revision.

\section{REFERENCES}

ARAGÃO, H. Ixodidas brasileiros e de alguns paizes limitrophes. Memórias do Instituto Oswaldo Cruz, v. 31, p. 759-843, 1936.

ARAGÃO, H.; FONSECA, F. Notas de Ixodologia VIII. Lista e chave para representantes da fauna Ixodológica Brasileira. Memórias do Instituto Oswaldo Cruz, v. 59, p. 115129, 1961.

BARKER, S.C.; MURRELL, A. Systematics and evolution of ticks with a list of valid genus and species names. Parasitology, v. 129(Suppl.), S15-S36, 2004.

BARROS-BATTESTI, D.M.; ONOFRIO, V.C.; LABRUNA, M.B.; MARTINS, J.R.; GUGLIELMONE, A.A. 
Redescription of Amblyomma fuscum Neumann, 1907 (Acari: Ixodidae), a rare South America tick confirmed in Brazil. Systematic Parasitology, v. 61, n. 2, p. 85-92, 2005. BOTELHO, M.C.N.; LEITE, L.M.R.M.; BASTOS, I.P.; SILVA, L.A.M.; CAMPELLO, M.L.C.B.; AGUIAR, M.C.A.; SERRA-FREIRE, N.M.; OLIVEIRA, J.B. Amblyomma dissimile Koch 1844 (Acari: Ixodidae) em mamíferos silvestres no Estado de Pernambuco, Brasil. Entomología y Vectores, v. 9, n. 1, p. 71-78, 2002.

BRUM, J.G.W.; VALENTE, A.L.S.; ALBANO, A.P.; COIMBRA, M.A.C.; GREQUE, G.G. Ixodidae de mamíferos silvestres atendidos no Núcleo de Reabilitação da Fauna Silvestre, UFPEL. Arquivos do Instituto Biológico, v. 70, n. 2, p. 211-212, 2003.

CUNHA, M.C.A.L.; FARIAS, A.M.I.; BRITO, F.L.C.; SERRA-FREIRE, N.M. Ocorrência de Amblyomma fuscum Neumann, 1907 (Acari: Ixodidae) em Boa constrictor Linnaeus, 1758 (Reptilia: Boidae) no estado de Pernambuco, Brasil. Entomología y Vectores, v. 6, n. 5, p. 577-579, 1999.

CUNHA, M.C.A.L.; FARIAS, A.M.I.; BRITO, F.L.C.; SERRA-FREIRE, N.M. Intensidade de parasitismo de Amblyomma rotundatum Koch, 1844 (Acari: Ixodidae) em serpentes da Família Boidae capturadas no Parque dois Irmãos, Recife, Pernambuco, Brasil. Entomología y Vectores, v. 10, n. 1, p. 21-29, 2003.

DANTAS-TORRES, F.; FIGUEREDO, L.A. Canine babesiosis: A Brazilian perspective. Veterinary Parasitology, v. 141, n. 3-4, p. 197-203, 2006.

DANTAS-TORRES, F.; OLIVEIRA-FILHO, E.F.; SOUZA, B.O.F.; SÁ, F.B. First record of Amblyomma rotundatum Koch, 1844 (Acari: Ixodidae) parasitizing Crotalus durissus cascavella (Wagler, 1824) (Squamata: Viperidae) in the State of Pernambuco, Brazil. Arquivos do Instituto Biológico, v. 72, n. 3, p. 389-390, 2005.

ESTRADA-PEÑA, A. Abnormal development of Rhipicephalus sanguineus (Ixodidae). Experimental and Applied Acarology, v. 25, n. 9, p. 757-761, 2001.

EVANS, D.E.; MARTINS, J.R.; GUGLIELMONE, A.A. A review of the ticks (Acari, Ixodida) of Brazil, their hosts and geographic distribution - 1. The state of Rio Grande do Sul, southern Brazil. Memórias do Instituto Oswaldo Cruz, v. 95, n. 4, p. 453-470, 2000.

GUIMARÃES, J.H.; TUCCI, E.C.; BARROS-BATTESTI, D.M. Ectoparasitos de importância veterinária. Editora Plêiade/FAPESP, São Paulo. 2001. 218p.

Jongejan F. \& Uilenberg G. 2004. The global importance of ticks. Parasitology, 129(Suppl.):S3-S14.

Keirans J.E. \& Durden L.A. 1998. Illustrated key to nymphs of the tick genus Amblyomma (Acari: Ixodidae) found in the United States. Journal of Medical Entomology, 35(4):489-495.
LABRUNA, M.B.; HOMEM, V.S.; HEINEMANN, M.B.; FERREIRA NETO, J.S. A case of gynandromorphism in Amblyomma oblongoguttatum (Acari: Ixodidae). Journal of Medical Entomology, v. 37, n. 5, p. 777-779, 2000.

LABRUNA, M.B.; RIBEIRO, A.F.; CRUZ, M.V.; CAMARGO, L.M.; CAMARGO, E.P. Gynandromorphism in Amblyomma cajennense and Rhipicephalus sanguineus (Acari: Ixodidae). Journal of Parasitology, v. 88, n. 4, p. 810-811, 2002.

LAMPO, M.; RANGEL, Y.; MATA, A. Genetic markers for the identification of two tick species, Amblyomma dissimile and Amblyomma rotundatum. Journal of Parasitology, v. 83, n. 3, p. 382-386, 1997.

MARQUES, S.; COL, R.D.; MATOS JUNIOR, M.O.; GONÇALVES, E.F.B.; PINTER, A.; LABRUNA, M.B. Parasitismo de Amblyomma fuscum (Acari: Ixodidae) em humanos. Ciência Rural, v. 36, n. 4, p. 1328-1330, 2006.

MARTINS, J.R.; MONTICELLI, E.C.; ONOFRIO, V.C.; BARROS-BATTESTI, D.M.; DOYLE, R.L. Primeiro relato de Amblyomma fuscum Neumann, 1907 (Acari: Ixodidae) parasitando lagarto da espécie Tupinambis teguixin (L.), no município de Glorinha, Estado do Rio Grande do Sul, Brasil. Revista Brasileira de Parasitologia Veterinária, v. 16, n. 4, p. 246-247, 2007.

NAVA, S.; LARESCHI, M.; REBOLLO, C.; BENÍTEZ USHER, C.; BEATI, L.; ROBBINS, R.G.; DURDEN, L.A.; MANGOLD, A.J.; GUGLIELMONE, A.A. The ticks (Acari: Ixodida: Argasidae, Ixodidae) of Paraguay. Annals of the Tropical Medicine and Parasitology, v. 101, n. 3, p. 255-270, 2007.

ONOFRIO, V.C.; LABRUNA, M.B.; PINTER, A.; GIACOMIN, F.G.; BARROS-BATTESTI, D. Comentários e chaves para as espécies do gênero Amblyomma. In: BARROSBATTESTI, D.M.; ARZUA, M.; BECHARA, G.H. (Eds). Carrapatos de Importância Médico-veterinária da Região Neotropical: um Guia Ilustrado para Identificação de Espécies. Vox/ICTTD-3/Butantan, São Paulo. 2006. p. 53-113.

SANTOS, E.M.; BOTELHO, M.C.N.; DE OLIVEIRA, J.B. Ectoparasitos de anfíbios anuros (Anura, Bufonidae) capturados na Estação Ecológica do Tapacurá, São Lourenço da Mata, Pernambuco, Brasil. Entomología y Vectores, v. 9, n. 1, p. 105-113, 2002.

SOCIEDADE BRASILEIRA DE HERPETOLOGIA. Brazilian amphibians: List of species. Available on: <http:/ /www.sbherpetologia.org.br>. Accessed in: 11 Aug. 2007a.

Sociedade Brasileira de Herpetologia. Brazilian reptiles: List of species. Available on: <http://www.sbherpetologia.org.br> . Accessed in: 11 Aug. 2007b.

TEIXEIRA, R.H.F.; AMORIM, M.; GAZETA, G.S.; SERRAFREIRE, N.M. Ixodofauna de répteis cativos no Zoológico de Sorocaba, São Paulo, Brasil. Entomología y Vectores, v. 10, n. 3,p. 319-329, 2003.

Received on October 25, 2007.

Accepted for publication on October 21, 2008. 